\title{
Prevalens dan Sebaran Faktor Risiko Mikosis Sistemik pada Neonatus dengan Sepsis Awitan Lambat di RS Dr. Cipto Mangunkusumo
}

\author{
Didik Wijayanto, Idham Amir, Retno Wahyuningsih, Endang Windiastuti
}

Departemen Ilmu Kesehatan Anak, Fakultas Kedokteran Universitas Indonesia - Rumah Sakit Cipto Mangunkusumo, Jakarta

\begin{abstract}
Latar belakang. Infeksi jamur sistemik merupakan salah satu penyebab morbiditas dan mortalitas pada neonatus dengan gejala klinis yang mirip dengan sepsis. Mengetahui prevalens, pola jamur, faktor risiko, profil klinis, terapi, dan luaran klinis diharapkan dapat mengurangi morbiditas dan mortalitas infeksi jamur pada neonatus.

Tujuan. Mengetahui prevalens dan faktor risiko mikosis sistemik pada neonatus dengan sepsis awitan lambat.

Metode. Studi potong lintang retrospektif dengan penelusuran rekam medis Departemen Ilmu Kesehatan Anak sejak bulan Januari 2005- Desember 2008.

Hasil. Seratus empat puluh satu neonatus mengalami sepsis awitan lambat, 10 subjek tidak memenuhi kriteria inklusi sehingga terdapat 131 subjek yang dapat dianalisis. Lima puluh lima (42\%) subjek terbukti mengalami infeksi mikosis sistemik. Manifestasi klinis yang mencolok adalah infeksi pada sistem respirasi dan gastrointestinal. Faktor risiko infeksi jamur yang ditemukan pada studi ini adalah pemasangan kateter intravena, nutrisi parenteral, dan masa rawat lama. Profil laboratorium yang jelas adalah trombositopeni, $\mathrm{CRP}>10$, dan rasio IT $>0,2$. Setelah dilakukan analisis multivariat dan regresi logistik maka faktor risiko yang bermakna adalah muntah, tidak diare, dan masa rawat lama.

Kesimpulan. Prevalens infeksi jamur sistemik pada sepsis awitan lambat $42 \%$ dengan penyebab Candida sp. Faktor risiko yang bermakna adalah muntah, tidak diare, dan masa rawat lama. (Sari Pediatri 2009;11(4):229-37).
\end{abstract}

Kata kunci: candida, sepsis, neonatus

\footnotetext{
Alamat korespondensi

Dr. Idham Amir, Sp.A(K). Divisi Perinatologi. Departemen Ilmu Kesehatan Anak FKUI-RSCM. Jl. Salemba no. 6. Jakarta 10430. Telepon: $021-3154020$
}

epsis merupakan salah satu penyebab utama kesakitan dan kematian neonatus terutama pada bayi berat lahir rendah (BBLR). Sepsis awitan lambat yaitu sepsis yang terjadi setelah usia tujuh hari, merupakan masalah penting pada 
neonatus dengan berat badan lahir sangat rendah (BBLSR). Stoll $\mathrm{dkk}^{1}$ melaporkan 1313 (21\%) dari 6215 neonatus yang bertahan hidup lebih dari tiga hari, memiliki satu atau lebih episode sepsis awitan lambat yang terbukti berdasarkan biakan darah. Duabelas persen kasus sepsis awitan lambat yang terjadi pada neonatus disebabkan oleh jamur. ${ }^{2}$

Mikosis sistemik terjadi antara lain karena sistem imun spesifik dan non spesifik neonatus masih belum sempurna. Faktor risiko infeksi jamur berupa penggunaan antibiotik lama, BBLR, usia gestasi kurang, dan penggunaan alat medik invasif. Apabila ada faktor risiko, neonatus menjadi lebih rentan terhadap infeksi sistemik yang dapat berakibat fatal. Komplikasi yang dapat terjadi adalah meningitis, gangguan ginjal, gangguan retina, dan vegetasi di dalam jantung sehingga membutuhkan waktu rawat yang lebih lama jika dibandingkan dengan tanpa komplikasi. Penelitian ini juga dilakukan untuk mengetahui angka kejadian dan pola jamur penyebab mikosis sistemik pada neonatus dengan sepsis awitan lambat secara retrospektif di Divisi Perinatologi IKA-RSCM.

\section{Metode}

Studi potong lintang retrospektif dilakukan pada data rekam medis Departemen Ilmu Kesehatan Anak FKUI - RSCM. Subjek adalah neonatus dengan sepsis awitan lambat yang dirawat di RSCM sejak 1 Januari 2005 hingga 31 Desember 2008. Pasien dengan data rekam medis yang tidak lengkap tidak diikutsertakan dalam penelitian. Besar sampel dihitung dengan formula estimasi proporsi populasi tunggal dengan angka ketepatan 5\% dan perkiraan prevalens mikosis sistemik pada sepsis awitan lambat sebesar 50\% sehingga diperoleh sampel minimal 163 orang.

Pencatatan rekam medis dilakukan untuk variabel manifestasi klinis (respirasi, kardiovaskular, gastrohepatologi, neurologi, renal, metabolik, kulit, mata), parameter laboratorium (Hemoglobin, Hematokrit, leukosit, trombosit, rasio IT, CRP, bilirubin, PT, PTT, GDS, AGD), faktor risiko intrinsik (neutropenia, berat lahir $<1500 \mathrm{~g}$, prematur, usia gestasi $<32$ minggu) dan ekstrinsik (lama pemberian antibiotik, kateter intravena, kortikosteroid, hiperalimentasi, ventilator lama, pembedahan, nutrisi parenteral, masa rawat lama), serta jenis terapi yang diberikan (flukonazol, amfoterisin B).
Sepsis awitan lambat didefinisikan sebagai sindrom klinis penyakit sistemik yang disertai bakteremia, umumnya terjadi setelah umur satu minggu kehidupan. Diagnosis mikosis dibagi menjadi tiga kategori, yaitu proven/pasti, jika ditemukan gejala sepsis, faktor risiko, dan biakan bahan klinik yang seharusnya steril (darah, cairan serebrospinal) memberikan hasil positif; probable, jika ditemukan gejala klinis, faktor risiko, dan bahan klinik yang tidak steril (feses) positif pada pemeriksaan dengan biakan; dan possible jika hanya ditemukan gejala klinis serta faktor risiko.

Data diolah dengan perangkat piranti lunak SPSS 15.0 dan disajikan secara deskriptif dan tabular. Persetujuan etik diperoleh dari Komite Etik Fakultas Kedokteran Universitas Indonesia.

\section{Hasil}

Selama kurun waktu 1 Januari 2005 sampai sampai 31 Desember 2008, ditemukan 3600 neonatus dengan sepsis neonatorum dan $141(3,9 \%)$ di antaranya didiagnosis sebagai sepsis awitan lambat. Sepuluh bayi tidak diikutsertakan karena rekam medis pasien tidak lengkap sehingga pada akhirnya didapatkan 131 kasus yang memenuhi kriteria penelitian.

Tabel 1. Karakteristik subjek penelitian

\begin{tabular}{lcc}
\hline Karakteristik & $\begin{array}{c}\text { Jumlah } \\
(\mathrm{n}=131)\end{array}$ & $\%$ \\
\hline Jenis kelamin & & \\
$\quad$ Laki-laki & 78 & 59,5 \\
$\quad$ Perempuan & 53 & 40,5 \\
$\quad$ Usia saat dirawat (hari) & & \\
$\quad \leq 7$ & 72 & 55,0 \\
$\quad>7$ & 59 & 45,0 \\
$\quad$ Berat lahir (gram) & & \\
$\quad<1500$ & 22 & 16,8 \\
$\quad$ 1500 & 109 & 83,2 \\
Masa gestasi (minggu) & & \\
$\quad<32$ & 23 & 17,6 \\
$\quad$ 232 & 108 & 82,4 \\
$\quad$ Riwayat persalinan & & \\
$\quad$ Spontan & 68 & 51,9 \\
$\quad$ Sectio saccaria & 46 & 35,1 \\
$\quad$ Ekstraksi vakum dan forseps & 17 & 12,9 \\
Luaran klinis & & \\
$\quad$ Hidup & 100 & 76,3 \\
$\quad$ Mati & 31 & 23,7 \\
\hline
\end{tabular}




\section{Karakteristik subjek penelitian}

Dijumpai 131 neonatus yang terbukti menderita sepsis awitan lambat, terdiri dari 59,5\% bayi laki-laki dan

Tabel 2. Karakteristik subjek yang terbukti mengalami infeksi Candida

\begin{tabular}{lcc}
\hline \multicolumn{1}{c}{ Karakteristik } & Jumlah & $\%$ \\
\hline Berat lahir (gram) & & \\
$\quad<1000$ & 0 & 0 \\
$1000-1500$ & 14 & 25,5 \\
1501-2500 & 20 & 36,4 \\
$\quad$ 2500 & 21 & 38,1 \\
Usia gestasi (minggu) & & \\
$\quad<32$ & 7 & 12,8 \\
32-37 & 24 & 43,6 \\
$\quad>37$ & 24 & 43,6 \\
Lama rawat & & \\
sebelum kultur positif (hari) & & \\
1 & 1 & 1,8 \\
$2-7$ & 5 & 9,2 \\
$8-14$ & 40 & 72,6 \\
$15-21$ & 6 & 11 \\
$22-30$ & 2 & 3,6 \\
$>30$ & 1 & 1,8 \\
\hline
\end{tabular}

40,5\% bayi perempuan. Karakteristik subjek penelitian tertera pada Tabel 1.

\section{Prevalens mikosis sistemik pada sepsis awitan lambat}

Diantara 131 neonatus dengan sepsis awitan lambat, 55 (42\%) terbukti mengalami mikosis sistemik, koloni sel ragi juga ditemukan pada pemeriksaan biakan darah bakteri, satu pada biakan darah pertama dan sepuluh pada biakan darah kedua. Neonatus dengan koloni sel ragi pada pemeriksaan biakan darah bakteri pertama merupakan neonatus cukup bulan dengan awitan gejala sepsis pada hari ke-15, takipnu, retraksi, hiperbilirubinemia, dan letargi. Karakteristik subjek dengan infeksi kandida tertera pada Tabel 2.

Sebaran jamur penyebab mikosis sistemik pada neonatus dengan sepsis awitan lambat

Biakan darah terhadap jamur dilakukan pada 76 dari 131 neonatus dengan sepsis awitan lambat. Pada biakan darah, koloni jamur dapat diisolasi pada 55 subjek, sedangkan pada 21 subjek lainnya tidak ditemukan

Tabel 3. Manifestasi klinis neonatus dengan sepsis awitan lambat

\begin{tabular}{lcccc}
\hline \multicolumn{1}{c}{ Gejala } & $\begin{array}{c}\text { Candida+ } \\
(\mathrm{n}=55)\end{array}$ & $\begin{array}{c}\text { Candida- } \\
(\mathrm{n}=76)\end{array}$ & $p$ & OR \\
\hline Sistem respirasi (n, \%) & & & & \\
$\quad$ Takipnu & $42(76,4)$ & $46(60,5)$ & 0,356 & $1,4(0,7-2,9)$ \\
$\quad$ Retraksi & $30(54,5)$ & $31(40,7)$ & 0,390 & $1,4(07-2,7)$ \\
$\quad$ Merintih & $7(12,7)$ & $11(14,5)$ & 0,620 & $0,8(0,3-2,1)$ \\
Sistem kardiovaskular (n, \%) & & & & \\
$\quad$ Takikardia & 0 & $8(10,5)$ & 0,009 & \\
$\quad$ Perfusi buruk & $18(32,7)$ & $24(31,6)$ & 0,822 & $0,9(0,4-1,9)$ \\
$\quad$ Edema & $1(1,8)$ & $3(3,9)$ & 0,431 & $0,4(0,04-4,0)$ \\
Sistem gastro-hepatologi (n, \%) & & & & \\
$\quad$ Sulit minum & $31(56,4)$ & $35(46)$ & 0,667 & $1,1(0,6-2,3)$ \\
$\quad$ Muntah & $12(21,8)$ & $6(7,9)$ & 0,069 & $2,6(0,9-7,5)$ \\
$\quad$ Perdarahan nasogastric tube & $6(10,9)$ & $7(9,2)$ & 0,886 & $1,1(0,3-3,4)$ \\
$\quad$ Diare & $3(5,4)$ & $12(15,8)$ & 0,044 & $0,3(0,07-1,0)$ \\
$\quad$ Kembung & $10(18)$ & $12(15,8)$ & 0,903 & $1,1(0,4-2,7)$ \\
Sistem neurologis (n, \%) & & & & \\
$\quad$ Kejang & $4(7,2)$ & $2(2,6)$ & 0,258 & $2,6(0,5-14,9)$ \\
Metabolik (n, \%) & & & & \\
$\quad$ Hiperglikemia & 0 & $1(1,3)$ & 0,371 & \\
Hipoglikemia & $2(3,6)$ & $3(3,9)$ & 0,844 & $0,8(0,1-5,1)$ \\
$\quad$ Instabilitas suhu & $24(43,6)$ & $39(51,3)$ & 0,171 & $0,6(0,3-1,2)$ \\
$\quad$ Hiperbilirubinemia & $5(9,7)$ & $12(15,8)$ & 0,844 & $0,8(0,1-5,1)$ \\
\hline
\end{tabular}


koloni jamur. Jenis jamur yang ditemukan dalam biakan tersebut seluruhnya adalah Candida sp.

\section{Manifestasi klinis dan profil laboratorium mikosis sistemik pada sepsis awitan lambat}

Tabel 3 menggambarkan sebaran manifestasi klinis mikosis sistemik pada sepsis awitan lambat. Pada sistem respirasi, takipnu merupakan manifestasi yang paling sering ditemukan baik pada terbukti mikosis sistemik $(76,4 \%)$ maupun tidak terbukti mikosis sistemik (60,5\%).

Perfusi yang buruk merupakan manifestasi kardiovaskular yang paling mencolok, ditemukan pada $32,7 \%$ yang terbukti menderita mikosis sistemik dan 31,6\% pada kelompok tidak terbukti mikosis sistemik. Gejala sistem gastro-hepatologi yang paling sering ditemukan adalah kesulitan minum, 56,4\% pada terbukti mikosis sistemik dan $46 \%$ pada tidak terbukti mikosis sistemik. Manifestasi neurologis kejang ditemukan pada 6 kasus, terdiri atas 4 kasus terbukti mikosis sistemik dan 2 kasus tidak terbukti mikosis sistemik. Instabilitas suhu merupakan manifestasi metabolik yang paling sering ditemukan yaitu 43,6\% kasus terbukti mikosis sistemik dan 51,3\% pada tidak terbukti mikosis sistemik. Manifestasi metabolik lain seperti hipoglikemia hanya ditemukan pada 5 kasus dan hiperglikemia pada satu kasus.

Profil laboratorium neonatus dengan sepsis awitan lambat tertera pada Tabel 4. Leukositosis dengan

Tabel 4. Profil laboratorium neonatus dengan sepsis awitan lambat

\begin{tabular}{|c|c|c|c|c|}
\hline Laboratorium & $\begin{array}{c}\text { Candida }+ \\
(n=55)\end{array}$ & $\begin{array}{c}\text { Candida- } \\
(n=76)\end{array}$ & $P$ & OR \\
\hline \multicolumn{5}{|c|}{ Hemoglobin (g/dL, n, \%) } \\
\hline$<14$ & $34(62)$ & $46(60,5)$ & 0,834 & $1,1(0,5-2,2)$ \\
\hline $14-24$ & $21(38)$ & $30(39,4)$ & & \\
\hline$>24$ & 0 & 0 & & \\
\hline \multicolumn{5}{|c|}{ Hematokrit (vol\%, n, \%) } \\
\hline$<44$ & $35(63)$ & $53(69,7)$ & 0,443 & \\
\hline $44-64$ & $19(35)$ & $23(30,2)$ & & \\
\hline$>64$ & $1(2)$ & 0 & & \\
\hline \multicolumn{5}{|l|}{ Leukosit $\left(\mathrm{mm}^{3}, \mathrm{n}, \%\right)$} \\
\hline$<6000$ & $16(29)$ & $18(23,6)$ & 0,127 & $1,7(0,8-3,4)$ \\
\hline $6000-30000$ & $37(67)$ & $43(56,5)$ & & \\
\hline$>30000$ & $2(4)$ & $15(19,7)$ & & \\
\hline \multicolumn{5}{|l|}{ Trombosit $\left(\mathrm{mm}^{3}, \mathrm{n}, \%\right)$} \\
\hline$<100000$ & $44(80)$ & $51(67,1)$ & 0,291 & \\
\hline $100000-300000$ & $9(16)$ & $17(22,3)$ & & \\
\hline$>300000$ & $2(4)$ & $8(10,5)$ & & \\
\hline \multicolumn{5}{|l|}{ IT ratio $(\mathrm{n}, \%)$} \\
\hline$\leq 0,2$ & $10(18)$ & $28(36,8)$ & & \\
\hline$>0,2$ & $45(82)$ & $48(63,1)$ & & \\
\hline \multicolumn{5}{|l|}{$\mathrm{CRP}(\mathrm{n}, \%)$} \\
\hline$<10$ & $10(18)$ & $28(36,8)$ & & \\
\hline$\geq 10$ & $45(82)$ & $48(63,1)$ & & \\
\hline \multicolumn{5}{|l|}{ Bilirubin $(\mathrm{mg} / \mathrm{dL})$} \\
\hline$\leq 12$ & $12(22)$ & $6(7)$ & 0,004 & $8,4(1,8-38,6)$ \\
\hline$>12$ & $5(9)$ & $12(15,7)$ & & \\
\hline \multicolumn{5}{|l|}{ GDS (mg/dL, n, \%) } \\
\hline$<47$ & $2(4)$ & 0 & & \\
\hline$\geq 47$ & $14(25)$ & $32(42,1)$ & & \\
\hline \multicolumn{5}{|l|}{$\operatorname{AGD}(\mathrm{n}, \%)$} \\
\hline Normal & $10(18)$ & $12(15,7)$ & 0,108 & $0,29(0,06-1,4)$ \\
\hline Asidosis & $8(15)$ & $20(26,3)$ & & \\
\hline
\end{tabular}


Didik Wijayanto dkk: Faktor risiko mikosis sistemik pada neonatus dengan sepsis

Tabel 5. Sebaran faktor risiko terjadinya mikosis sistemik pada neonatus dengan sepsis awitan lambat

\begin{tabular}{lcccc}
\hline Faktor risiko & $\begin{array}{c}\text { Candida }+ \\
(\mathrm{n}=55)\end{array}$ & $\begin{array}{c}\text { Candida- } \\
(\mathrm{n}=76)\end{array}$ & $p$ & OR \\
\hline Intrinsik (n, \%) & Tidak ada data & Tidak ada data & & \\
$\quad$ Netropenia & $10(18)$ & $12(15,7)$ & 0,764 & $1,1(0,5-2,6)$ \\
$\quad$ Berat lahir $<1500 \mathrm{~g}$ & $10(18)$ & $13(17)$ & 0,121 & $0,5(0,2-1,2)$ \\
$\quad$ Usia gestasi $<32$ minggu & & & & \\
Ekstrinsik (n, \%) & & & & \\
Lama pemberian antibiotik & $14(25,5)$ & $76(100)$ & & \\
$\quad<7$ hari & $41(74,5)$ & $68(89,4)$ & 0,108 & $3,4(0,7-16,9)$ \\
$\geq 7$ hari & $53(96)$ & $1(1,3)$ & & \\
Kateter intravena & $1(2)$ & $10(13,1)$ & & \\
$\quad$ Kortikosteroid & $5(9)$ & $3(3,9)$ & & \\
$\quad$ Ventilator lama & $5(9)$ & $60(78,9)$ & 0,002 & $7,8(1,7-35,7)$ \\
$\quad$ Pembedahan & $53(96)$ & $58(76,3)$ & 0,001 & $9,1(2,0-41,3)$ \\
$\quad$ Nutrisi parenteral & $53(96)$ & & & \\
$\quad$ Masa rawat lama & & & \\
&
\end{tabular}

kadar leukosit $>30000 / \mu \mathrm{L}$ ditemukan pada $4 \%$ dari kelompok terbukti mikosis sistemik dan sebesar 19,7\%, pada kelompok tidak terbukti mikosis sistemik. Kadar bilirubin berbeda bermakna secara statistik antara kelompok dengan kultur Candida positif dibandingkan dengan tidak.

\section{Sebaran faktor risiko terjadinya mikosis sistemik pada neonatus dengan sepsis awitan lambat}

Tabel 5 menggambarkan sebaran faktor risiko mikosis sistemik pada neonatus dengan sepsis awitan lambat. Nutrisi parenteral sebagai faktor risiko ekstrinsik mikosis sistemik ditemukan 96\% pada kelompok terbukti mikosis sistemik, sedangkan pada kelompok tidak terbukti mikosis sistemik 78,9\%. Masa rawat lebih dari tujuh hari ditemukan 96\% pada kelompok terbukti mikosis sistemik, dan 76,3\% pada kelompok tidak terbukti mikosis sistemik. Rerata lama rawat pada kelompok terbukti mikosis sistemik adalah 37 hari dan untuk kelompok tidak terbukti mikosis sistemik 28 hari.

\section{Penggunaan antijamur pada neonatus sepsis awitan lambat}

Amfoterisin B merupakan jenis antijamur yang paling sering digunakan yaitu pada 39 dari 55 neonatus yang mempunyai biakan darah koloni kandida, sedangkan flukonazol digunakan pada 9 orang pasien (Tabel 6). Amfoterisin B juga diberikan pada 13 dari 76 neonatus yang tidak terbukti mempunyai jamur pada pemeriksaan biakan darah jamur atau tidak dilakukan pemeriksaan biakan darah jamur. Secara keseluruhan, amfoterisin B digunakan pada 39,7\% neonatus dengan sepsis awitan lambat.

Tabel 7 menunjukkan sebaran luaran klinis berdasarkan jenis obat anti jamur yang digunakan. Jumlah pasien yang hidup lebih banyak ditemukan pada neonatus yang mendapat amfoterisin B (75\%) dibandingkan yang diobati dengan flukonazol $(46,6 \%)$.

Tabel 6. Sebaran penggunaan anti jamur pada neonatus sepsis awitan lambat

\begin{tabular}{lcc}
\hline Jamur & Amfoterisin B & Flukonazol \\
\hline Candida $(+)$ & 39 & 9 \\
Candida $(-)$ & 13 & 6 \\
\hline Total & 52 & 15 \\
\hline
\end{tabular}

Tabel 7. Sebaran luaran klinis berdasarkan jenis obat anti jamur yang digunakan

\begin{tabular}{llc}
\hline Obat anti jamur & \multicolumn{2}{c}{ Luaran klinis } \\
\cline { 2 - 3 } & Hidup & Mati \\
\hline Amfoterisin B (n, \%) & $39(75)$ & $13(25)$ \\
Flukonazol (n, \%) & $7(46,6)$ & $8(53,4)$ \\
\hline
\end{tabular}


Didik Wijayanto dkk: Faktor risiko mikosis sistemik pada neonatus dengan sepsis

Tabel 8. Regresi logistik

\begin{tabular}{llcccccccl}
\hline & Variabel & Koefisien & S.E. & Wald & df & $p$ & OR & min & \multicolumn{1}{c}{ Maks } \\
\hline Step 8(a) & Muntah (1) & 1.68 & 0.69 & 5.98 & 1 & 0.014 & 5.35 & 1.40 & 20.54 \\
& Diare (1) & -1.75 & 0.76 & 5.36 & 1 & 0.021 & 0.17 & 0.04 & 0.76 \\
& Masa rawat (1) & 2.70 & 0.85 & 10.04 & 1 & 0.002 & 14.93 & 2.80 & 79.47 \\
& Konstanta & -2.68 & 0.84 & 10.10 & 1 & 0.001 & 0.07 & & \\
\hline
\end{tabular}

\section{Analisis multivariat}

Berdasarkan analisis multivariat dengan regresi logistik multistep, diperoleh variabel yang berhubungan bermakna dengan mikosis sistemik adalah muntah, tidak diare, dan masa rawat lama (Tabel 8). Persamaan regresi logistik yang diperoleh adalah,

$Y=-2,677+1,68 a+(-) 1,751 b+2,703 c$

Keterangan: a: muntah; $y a=1$, tidak $=0$

b: tidak diare; $y a=1$, tidak $=0$

c: masa rawat lama; $y a=1$, tidak $=0$

\section{Pembahasan}

Prevalens sepsis awitan lambat pada neonatus dengan diagnosis sepsis neonatorum pada penelitian kami adalah 3,9\%. Penelitian meliputi 131 neonatus yang terbukti mengalami sepsis awitan lambat, 59,5\% bayi laki-laki dan $40,5 \%$ perempuan. Hal ini tidak jauh berbeda dengan kepustakaan yang menyatakan bahwa tidak ada perbedaan angka kejadian sepsis awitan lambat berdasarkan jenis kelamin. ${ }^{42}$

Didapatkan $83,2 \%$ subjek penelitian memiliki berat badan $\geq 1500$ gram dan 16,8\% memiliki berat badan $<1500$ gram. The National Institute of Child Health and Human Development (NICHD) neonatal research network yang melaporkan $25 \%$ bayi berat badan lahir sangat rendah menderita sepsis awitan lambat. ${ }^{42,43}$ Sedangkan The Centers for Disease Control and Prevention National Nosocomial Infection Surveillance System juga melaporkan bahwa 15\%-20\% bayi dengan berat lahir $<1500$ gram menderita sepsis awitan lambat. ${ }^{42,43}$

Risiko terjadinya sepsis awitan lambat makin tinggi dengan makin mudanya usia gestasi terutama usia gestasi $<28$ minggu dan makin rendahnya berat badan lahir, terutama berat badan lahir $<1500$ gram. ${ }^{42-}$ ${ }^{44}$ Pada penelitian kami juga didapatkan bahwa $82,4 \%$ subjek berusia $\geq 32$ minggu dan hanya $17,6 \%$ berusia $<32$ minggu, sejalan dengan proporsi berdasarkan berat badan bayi. Perbedaan ini mungkin terjadi karena bayi yang dirawat dengan sepsis di RS Cipto Mangunkusumo sebagian besar adalah bayi cukup bulan dengan berat badan lahir $\geq 1500$ gram atau hal ini dapat merupakan tanda bahwa angka infeksi nosokomial di RS Cipto Mangunkusumo masih cukup tinggi sehingga bayi dengan berat lahir cukup dan cukup bulan juga rentan terhadap infeksi atau populasi ibu yang datang melahirkan ke RS Cipto Mangunkusumo adalah ibu yang memiliki risiko tinggi infeksi pada janin.

Leibovitz ${ }^{3}$ melaporkan angka mortalitas sebesar 25\%-54\%. Angka mortalitas pada pada penelitian ini lebih kecil mungkin lebih disebabkan karena jumlah subjek pada penelitian ini lebih banyak yang usia gestasinya cukup bulan dan memiliki berat badan $\geq 1500$ gram sehingga secara umum sistim imunologisnya lebih baik dibandingkan bayi prematur atau bayi dengan berat badan $<1500$ gram. Angka mortalitas sepsis awitan lambat pada penelitian ini ditemukan sebesar $23,7 \%$, lebih kecil jika dibandingkan dengan angka yang dilaporkan oleh NICHD 45\%. ${ }^{42}$

Empat puluh dua persen neonatus dengan sepsis awitan lambat terbukti menderita mikosis sistemik. Pada kelompok neonatus dengan candida positif sebagian besar lahir dengan berat $>2500 \mathrm{~g}$ dan cukup bulan. Sebagian besar neonatus dengan kandida positif terbukti mengalami mikosis sistemik pada perawatan hari ke 8-14. ${ }^{3}$ Infeksi jamur disebabkan oleh Candida sp, seperti dilaporkan oleh Wahyuningsih dkk, ${ }^{5}$ Candida (81\%). Hal ini menunjukkan bahwa belum terjadi pergeseran organisme penyebab mikosis sistemik dalam delapan tahun terakhir.

Lamagni $\mathrm{dkk}^{4}$ juga menemukan bahwa spesies jamur penyebab infeksi invasif pada neonatus tersering adalah Candida sp. (97,6\%), sedangkan spesies lain seperti Aspergilus sp. dan Malasezzia sp. masing-masing 
1,2\%. ${ }^{4}$ Pfaller $\mathrm{dkk}^{9}$ melaporkan bahwa Candida albicans merupakan penyebab tersering infeksi jamur neonatus 53\%-60\%. Data dari CDC, NNIS, SENTRY juga menunjukkan bahwa Candida albicans adalah penyebab tersering infeksi jamur pada neonatus disusul oleh Candida tropicalis, ${ }^{9}$ Wahyuningsih $\mathrm{dkk}^{5}$ (20012003) menemukan penyebab tersering infeksi jamur pada neonatus yang dirawat di Divisi Perinatologi RS Cipto Mangunkusumo adalah Candida tropicalis (48,5\%), Candida guilliermondii (14,7\%) dan Candida albicans $(11,8 \%)$. Agarwal $\mathrm{dkk}^{34}$ dalam penelitiannya menyatakan bahwa meskipun penyebab tersering mikosis sistemik pada neonatus adalah Candida albicans akan tetapi terdapat kecenderungan meningkatnya mikosis sistemik yang disebabkan oleh non-C.albicans.

Manifestasi klinis sepsis awitan lambat yang mencolok baik pada kasus yang terbukti mikosis sistemik maupun tidak terbukti mikosis sistemik adalah adanya keterlibatan sistem respirasi yaitu timbulnya sindrom gawat napas (takipnu, retraksi, dan merintih) dan gangguan sistem gastrointestinal (sulit minum, muntah, perdarahan per NGT, diare, kembung). Manifestasi neurologis yaitu kejang hanya ditemukan pada total 6 dari 131 neonatus sepsis awitan lambat yaitu 4 kasus terbukti mikosis sistemik dan 2 kasus tidak terbukti mikosis sistemik. Penelitian Makhoul $\mathrm{dkk}^{44}$ di Israel juga menunjukkan bahwa manifestasi klinis sistem respirasi dan gastrointestinal merupakan gejala klinis yang paling menonjol pada neonatus dengan sepsis awitan lambat. Manifestasi klinis sepsis awitan lambat ini pada umumnya tidak berbeda dengan sepsis awitan dini, kecuali pada insidens terjadinya meningitis yang didapatkan lebih tinggi pada sepsis awitan lambat. ${ }^{44-46}$

Profil darah tepi (kadar hemoglobin, hematokrit, leukosit, trombosit) neonatus sepsis awitan lambat tidak jauh berbeda antara kelompok terbukti mikosis sistemik dengan kelompok tidak terbukti mikosis sistemik (Tabel 5). Leukositosis dengan kadar leukosit $>30.000 / \mu \mathrm{L}$ ditemukan dalam proporsi yang lebih tinggi pada kelompok tidak terbukti mikosis sistemik (19,7\%) dibandingkan kelompok terbukti mikosis sistemik (4\%). Proporsi trombositopenia dengan kadar trombosit $<100.000 / \mu \mathrm{L}$ didapatkan dalam proporsi yang jauh lebih tinggi pada kelompok terbukti $(80 \%)$ mikosis sistemik dibandingkan dengan kelompok tidak terbukti $(67,1 \%)$ mikosis sistemik. Sesuai dengan hasil penelitian Benjamin $\mathrm{dkk}^{6}$ yang menyatakan bahwa trombositopenia merupakan faktor yang berhubungan bermakna dengan insidens kandidemia.

Benjamin $\mathrm{dkk}^{6}$ membuat kriteria skor kandidemia untuk menuntun pemberian anti jamur secara empiris pada neonatus BBLSR. Kriteria tersebut meliputi trombositopenia, mendapatkan sefalosporin generasi III atau carbapenem, usia gestasi 25-27 minggu, atau usia gestasi<25 minggu. Skor $>2$ diklasifikasikan sebagai positif. Hasil penelitian ini diharapkan dapat digunakan sebagai data dasar sebagai upaya untuk membuat suatu kriteria skoring yang akan menuntun kita dalam pemberian anti jamur empiris sebelum didapatkan hasil kultur jamur.

Pemberian nutrisi parenteral, penggunaan kateter intravena, dan masa rawat yang lama didapatkan dalam proporsi yang jauh lebih tinggi pada kelompok terbukti mikosis sistemik dibandingkan dengan kelompok tidak terbukti mikosis sistemik. Hasil ini sejalan dengan penelitian Benjamin $\mathrm{dkk}^{6}$ yang membandingkan faktor risiko timbulnya kandidemia dengan risiko terjadinya sepsis awitan lambat oleh coagulase negative Staphylococcus yang mendapatkan hasil bahwa penggunaan antibiotik sefalosporin generasi III, penggunaan kortikosteroid, penggunaan kateter sentral, penggunaan kortikosteroid, serta pemberian nutrisi parenteral merupakan faktor risiko bermakna kandidemia.

Proporsi lama penggunaan antibiotik $\geq 7$ hari baik lini pertama dan lini kedua tidak berbeda antara kedua kelompok yaitu masing-masing $42 \%$ dan $44,7 \%$ untuk lini pertama, 56\% dan 52,6\% untuk lini kedua. Pada kelompok terbukti mikosis sistemik ditemukan bahwa penggunaan antibotik lini ketiga $\geq 7$ hari lebih tinggi daripada kelompok tidak terbukti mikosis sistemik (33\% versus 15,7\%), hal ini konsisten dengan kepustakaan yang menyatakan bahwa penggunaan antibiotik spektrum luas lebih dari 7 hari merupakan salah satu faktor risiko ekstrinsik terjadinya mikosis sistemik. . $^{3-6} \mathrm{Jika}$ ditelaah lebih lanjut 82,6\% neonatus pada kelompok yang terbukti mikosis sistemik mendapatkan antibiotik $\geq 7$ hari sebelum dilakukan biakan darah jamur, dengan $61,8 \%$ selama $7-14$ hari dan 19,7\% lebih dari 14 hari. Lama pemakaian antibiotik $\geq 7$ hari terbukti merupakan risiko terjadinya mikosis sistemik. ${ }^{3-6}$

Penggunaan ventilator lama, kortikosteroid lama, pembedahan, dan hiperalimentasi tidak berbeda antara kedua kelompok. Pemberian nutrisi parenteral, penggunaan kateter intravena, masa rawat yang lama, serta pemakaian antibiotik $\geq 7$ hari merupakan faktor 
risiko ekstrinsik terjadinya mikosis sistemik.

Jenis anti jamur yang paling sering digunakan adalah amfoterisin B, 68\% dari total anti jamur yang digunakan dan $17 \%$ diantaranya digunakan untuk neonatus kelompok tidak terbukti mikosis sistemik yang tidak tumbuh jamur pada pemeriksaan kultur jamur atau yang tidak dilakukan pemeriksaan jamur. Penggunaan amfoterisin B lebih efektif dibandingkan dengan flukonazol berdasarkan luaran klinisnya. Dijumpai $75 \%$ neonatus yang mendapat amfoterisin $B$ berhasil selamat (hidup), sedangkan pada neonatus yang mendapat flukonazol hanya 46,6\%. Sesuai dengan konsensus yang dianut saat ini yang menyatakan bahwa amfoterisin B merupakan obat anti lini pertama untuk mengatasi mikosis sistemik. 3,33,34,36,41

Berdasarkan analisis multivariat dan regresi logistik didapatkan bahwa faktor risiko adalah muntah, tidak diare, dan masa rawat yang lama. Faktor risiko lainnya tidak terbukti, hal ini dapat disebabkan jumlah sampel penelitian kurang dan tidak semua mendapat perlakuan yang sama. Tidak diare sebagai faktor risiko tidak sesuai dengan kepustakaan yang ada. Sejalan dengan penelitian Makhoul $\mathrm{dkk}^{44}$ di Israel yang melaporkan manifestasi sistem respirasi dan gastrointestinal merupakan yang terbanyak pada sepsis awitan lambat.

Sebagai kesimpulan pada neonatus dengan sepsis awitan lambat didapatkan $42 \%$ neonatus menderita mikosis sistemik dengan penyebab tersering Candida sp. Manifestasi klinis sepsis awitan lambat yang cukup dominan adalah gejala sistem respirasi dan sistem gastrointestinal. Faktor risiko mikosis sistemik adalah muntah, tidak diare, dan masa rawat lama. Amfoterisin B cukup efektif sebagai terapi lini pertama mikosis sistemik pada neonatus. Penelitian prospektif lebih lanjut perlu dilakukan untuk mengetahui jenis spesies jamur penyebab dan resistensinya serta mengetahui faktor risiko mikosis sistemik pada neonatus dengan sepsis.

\section{Daftar Pustaka}

1. Bizzarro MJ, Raskin C, Baltimore RS, Gallagher PG. Seventy-five years of neonatal sepsis at Yale:1928-2003. Pediatrics 2005;116:595-602.

2. Stoll BJ, Hansen N, Fanaroff AA, Wright LL, Carlo WA, Ehrenkranz RA, dkk. Late onset sepsis in very low birth weight neonates:The experience of NICHD neonatal research network. Pediatrics 2002;110:285-291.
3. Leibovitz E. Neonatal candidiasis: epidemiologic, clinical and therapeutic aspects. Infect Med 2003;20:494-8.

4. Lamagni TL, Clerihew L, Mc Guire W. UK enhanced surveillance study of invasive fungal infection in very low birth weight infants. Commun Dis Rep CDR 2003;13:994.

5. Wahyuningsih R, Rozalyani A, El Jannah SM, Amir I, Prihartono J. Kandidemia pada neonatus yang mengalami kegagalan terapi antibiotik. Maj Kedokt Indon 2008;58:110-5.

6. Benjamin Jr DK, DeLong ER, Steinbach WJ, Cotton CM, Walsh TJ. Empirical therapy for neonatal candidemia in very low birth weight infants. Pediatrics 2003;112:543-7.

7. Donnely JP. Systemic fungal infection and the immunocompromized patients contemporary challenges in risk assessment and diagnosis. Abstract The third international symposium: Optimising management strategies for systemic fungal infection. Portugal 2002.

8. Rasmin M, Syarifudin PK, Setiawati A, Soemitro D, Hamid A, Wahyuningsih R, dkk. Tatalaksana mikosis sistemik. Dalam: Budimulya V, Bramono K, Zinuwih $S$, penyunting. Konsensus FKUI dan PMKI. Jakarta: Perhimpunan Mikologi Kedokteran dan Hewan Indonesia;2001.h.1-3.

9. Pfaller MA, Diekema DJ, Jones RN, Messer SA, Hollis RJ. Trends in antifungal susceptibility of candida sp isolated from pediatric and adult patients with bloodstream infections; SENTRY antimicrobial surveillance program,1997 to 2000. J Clin Microbiol 2002;40:852-6.

10. Ellis DH. Clinical Mycology: the human opportunistic mycones. Australia: Pfizer Inc Gillinghan Printers Pty Ltd;1994.h.17-39.

11. Malassezia sp. [Diakses tanggal 5 Januari 2008] Diunduh dari http://www.doctorfungus.org.

12. Aspergillosis and HIV. [Diakses tangggal 5 Februari 2008] Diunduh dari http://www. hivinsite.ucsf.edu.

13. Epidemiology and clinical aspects of unusual fungal nosocomial infections. [Diakses tanggal 5 Februari 2008] Diunduh dari http://www.nfid.org/publications/clinicalupdates/ fungal/noso.htm.

14. Suprihatin SD. Kandida dan Kandidiasis pada manusia. Jakarta: Balai Penerbit FKUI; 1982.h.9-24.

15. Maertens J, Vrebos M, Boogaerts M. Assessing risk factors for systemic fungal infections. Eur J Cancer Care 2001;10:56-62.

16. Tiraboschi IN, Bennet JE, Kauffman JA, Rex JH, Girmenia C, Sobel JD, dkk. Deep candida infections in 
the neutropenic and non-neutropenic hosts. Med Mycol 2000;38: 199-204.

17. Verweij PE, Poulain D, Obayashi T, Patterson TF, Wenning DW, Penton J. Current trends in the detection of antigenemia, metabolites and cell wall markers for the diagnosis and therapeutic monitoring of fungal infections. Med Mycol 1998;36:146-55.

18. Lopez Sastre JB, Coto Cotallo GD, Fernandez CB. Neonatal invasive candidiasis: a prospective multicenter study of 118 cases. Am J Perinatol 2003;20:153-63.

19. Leibovitz E. Neonatal candidosis: clinical, management controversies and consensus, and new therapeutic options. J Antimicrob Chemoter 2002;49:69-73.

20. Warris A, Semmerkot BA, Voss A. Candidal and bacterial bloodstream infection in premature neonates: a case control study. Med Mycol 2001;39:75-9.

21. Burnie JP, Odds FC, Lee W, Webster C, Williams JD. Outbreak of systemic Candida albicans in the intensive care unit cause by cross infection. Br Med J 1985;290:746-8.

22. Fraser C. Cross-infection and diversity of Candida albicans strain carriage in patients and nursing staff in an intensive care unit. J Vet Med Mycol 1990;28:317-25.

23. Davis LE. Fungal infections of the central nervous system. Neurol Clin 1999;17:761-81.

24. Vasquez JA, Sobel JD. Candidiasis. Dalam: Dismukes WE, Pappas PG, Sobel JD, penyunting. Clinical Mycology. New York: Oxford University Pres; 2003. h.143-87.

25. Gomela TL, Cunningham MD, Eyal FG, Zenk KE. Management, procedures, on call problems, diseases, and drugs. Dalam: Gomella TL, Cumminghan MD, Eyal FG, Zenk KE, penyunting. Neonatology. Edisi 5. New York: Mc Graw Hill; 2004.h.435-6.

26. Volpe JJ. Bacterial and fungal intracranial infections. Neurology of the newborn. Edisi ke-3. Philadelphia: WB Saunders;1995.h. 730-66.

27. Fernandez M, Moylett EH, Noyola DE, Baker CJ. Candidal meningitis in neonates: a 10 year review. Clin Infect Dis 2000;31:458-63.

28. Benjamin DK, De Long ER, Steibach WJ, Cotton CM, Walsh TJ, Clark RH. Empirical therapy for neonatal candidemia in very low birth weight infants. Pediatrics 2003;112:543-57.

29. Kaufman D, Boyle R, Hazen KC, Patrie JT, Robinson M, Donowitz LG. Fluconazole prophylaxis against fungal colonization and infection in preterm infants. N Engl J Med 2001;345:1660-6.

30. Inamada AC, Palit A. The genus Malassezia and human disease. Indian J Dermatol Venereol Leprol 2000;69:26570.

31. Aspergillosis. [Diakses tanggal 10 Februari 2008] Diunduh dari http://www.emedicine.com/PED/topic148. htm.

32. Trichosporon infections. [Diakses tanggal 10 Februari 2008] Diunduh dari http://www.emedicine.com/cgi.bin/ foxweb.exe.

33. Rex JH. Practice guidelines for the treatment of candidiasis. Clin Infect Dis 2000;30:662-78.

34. Agarwal J, Bansal S, GK Malik, Jain A. Trends in neonatal septicemia: Emergence of non albicans candida. Indian Pediatrics 2004;41:712-5.

35. Gagneur A, Sizun J, Vernotte E, De Parscau L, Quinio D, Le Flohic AM, dkk. Low rate of candida parapsilosis related colonization and infection in hospitalized preterm infants: A one year prospective study. Hosp Inf J 2001;48:193-7.

36. Kingo AR, Smyth JA, Waisman D. Lack of evidence of amphotericin B toxicity in very low birth weight infants treated for systemic candidiasis. Pediatr Infect Dis J 1997;16:1002-03.

37. William KM, Kearns GL. Lipid amphotericin preparations. Pediatr Infect Dis J 2000;19:567-9.

38. Kicklighter SD. Antifungal agents and fungal prophylaxis in the neonate. Neoreviews 2002;3:252.

39. Candida spp. [Diakses tanggal 13 April 2009] Diunduh dari http://www.doctorfungus.org/thefungi/candida.

40. Caspofungin. [Diakses tanggal 13 April 2009] Diunduh dari http://www.merck.com/product/usa/candicas.

41. Al Mohsen I, Walter T, Hughes. Systemic antifungal therapy: past, present and future. Annals of Saudi Med 1998;18:28-38.

42. Gordon A, Isaacs D. Late onset sepsis and the role of antibiotic prescribing policies. Curr Opin Infect Dis 2004;17:231-6.

43. Stoll BJ, Gordon T, Korones SB, Shankaran S, Tyson JE, Bauer CR, dkk. Late-onset sepsis in very low birth weight neonate: a report from the National Institute of Child Health and Human Development Neonatal Research Network. J Pediatr 1996;129:63-71.

44. Makhoul IR, Sujov P, Smolkin T, Lusky A, Reichman B. Epidemiological, clinical, and microbiological characteristics of late-onset sepsis among very low birth weight infants in Israel: a national survey. Pediatrics 2002;109:34-9.

45. Pagana KD, Pagana TJ. Manual of diagnostic and laboratory tests. Edisi ke-2. Missouri: Mosby’s;1998.h.172337.

Sari Pediatri, Vol. 11, No. 4, Desember 2009 